Proc. Estonian Acad. Sci. Geol., 2001, 50, 1, 43-50

\title{
THE SHELL STRUCTURE AND MINERALOGY OF MICKWITZIA (LINGULATA: BRACHIOPODA) FROM THE LOWER CAMBRIAN KAKUMÄE BEDS OF ESTONIA
}

\author{
Jüri NEMLIHER \\ Institute of Geology, Tallinn Technical University, Estonia pst. 7, 10143 Tallinn, Estonia; \\ nemliher@gi.ee \\ Received 11 April 2000, in revised form 3 May 2000 \\ Abstract. XRD analysis shows that phosphatic pebbles and Mickwitzia valves from the Kakumäe \\ Beds consist of apatite, pyrite, and quartz. The apatite of valves is well crystallized F-apatite with \\ a moderate carbonate content $(0.2-3.4 \%)$. The lattice parameter $a$ of F-apatite ranges from 9.345 \\ to $9.367 \AA$ and $c$ from 6.881 to $6.887 \AA$. Pebbles contain the same apatite variety. Although the \\ valve sculpture is variously preserved, the shell structures appeared to be lost. Shells consist of \\ apatite-cemented quartzose silt and sand. The observed structure and mineral composition have \\ formed via phosphatization of a primarily organic-rich shell.
}

Key words: Lingulata, shell apatite, shell structure, Lower Cambrian.

\section{INTRODUCTION}

In the Kakumäe Beds of Early Cambrian age, lenses of conglomerate rich in brachiopod shells having an elevated phosphorus content can be found (Mens \& Pirrus 1977). Phosphorus is bound in apatite of lingulate brachiopods Paterina and Mickwitzia (Gorjansky 1969) and phosphatic pebbles (Mens \& Pirrus 1977). Owing to the extremely poor preservation of shells, the identification of taxa is often complicated. However, the ventral valves of Mickwitzia monilifera (Linnarsson 1869) can be identified with confidence.

The brachiopods from the Kakumäe section have for a long time been an object of mostly palaeontological studies (e.g. Schmidt 1888; Öpik 1925; Gorjansky 1969). Recently, also the isotopic and REE composition of Mickwitzia shells has been analysed (Lécuyer et al. 1998). 
Representatives of the genus Mickwitzia in different states of preservation occur in the Lower Cambrian (McMenamin 1992). Earlier studies have shown that their shell is built up of three layers: outer - pustulose, middle - with fine reticulate ornament, and inner - coarsely punctuate (Rowell 1965). Later, it has been established that the shell wall in Mickwitzia is composed of three layers, all of which are punctuate (McMenamin 1987, 1992). Also, the shell structure has been used as a diagnostic character at the species level (McMenamin 1992).

According to Williams \& Cusack (1999), lingulate brachiopods have baculated shells. This structure type first appeared in the Early Cambrian. It reveals rhythmic alternation of mineralized and baculi-containing layers, perfectly preserved in, e.g., Upper Cambrian Ungula ingrica (Holmer 1989).

Mineralogical studies have shown that Mickwitzia shells consist of phosphatic matter (Linnarsson 1869; Gorjansky 1969; McMenamin 1992). An analysis of shell apatite of Upper Cambrian to Lower Ordovician obolid brachiopods (Nemliher \& Puura 1996b) has revealed the importance of a more detailed characterization of fossil shell mineral in order to interpret both, post mortem burial conditions as well as primary properties of the biomineral.

This short note is an attempt to describe the structure and composition of Mickwitzia shells and to find out the possible pathways of their formation.

\section{MATERIALS AND METHODS}

The material for this research originates from the Muraste, Kakumäe, KoseLükati, and Kunda River outcrops and Kunda quarry (Fig. 1). A total of five

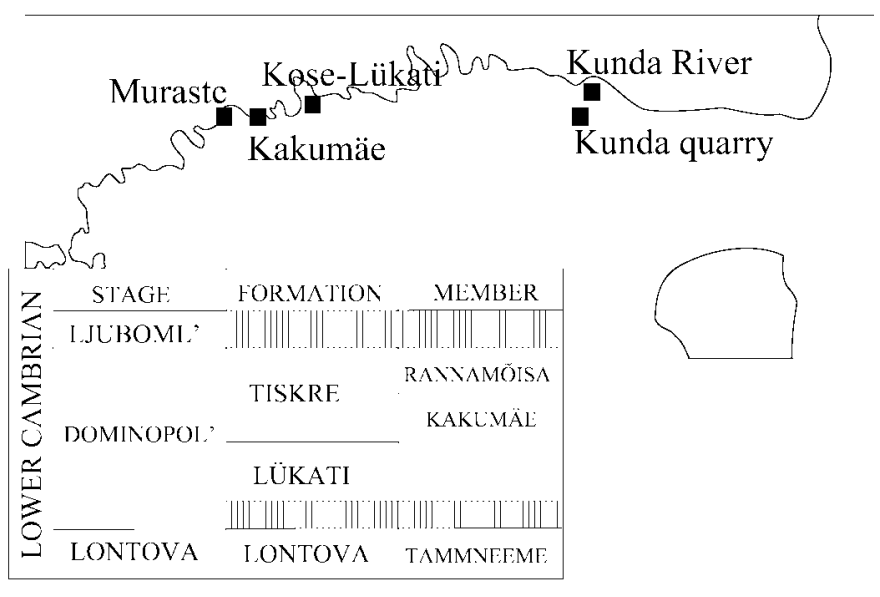

Fig. 1. Location of the outcrops and stratigraphic position of the samples studied. 
valves of Mickwitzia sp. and three phosphatized pebbles of the same stratigraphic range were examined by means of scanning electron microscopy (SEM) and $\mathrm{X}$-ray diffraction (XRD).

The SEM studies were carried out on cross-sections of valves, on fractured and polished, etched $(6 \% \mathrm{HCl})$ and untreated gold-coated surfaces. The XRD studies were performed using an HZG-4 diffractometer with Fe-filtered Coradiation $\left(\lambda_{\mathrm{K} \alpha 1}=1.788965 \AA\right)$; ranges of $28-44^{\circ}$ and $53-65^{\circ}$ of $2 \Theta$ were scanned (in step-scan mode, step $0.02^{\circ}$, counting time $5 \mathrm{~s}$ ). Independent least-squares curve-fitting was applied to each reflection in order to find the exact positions of 15 apatite reflections. During the whole-pattern-fitting the peak positions, halfwidths, and linear intensities were varied; the modified Lorenzian curve was used as the profile-shape-function. The background level was assumed to be linear and was found separately for both ranges. Quartz was used as internal standard; linear correction over both ranges was made. The lattice parameters of apatite were calculated using the least-squares method and the carbonate content of this mineral was determined by the equation of Schuffert et al. (1990). The presence of other minerals was detected by reflections on XRD patterns.

\section{RESULTS AND DISCUSSION}

The studied shells are variously preserved (Pl. I, fig. 1). Fossils are mostly pseudomorphs of shells (Pl. I, fig. 1A), but well-ornamented shells can be found as well (Pl. I, fig. 1B).

The mineralogical composition of the shells as well as of pebbles consists of F-apatite with a moderate carbonate content, quartz and pyrite. The crystallinity of apatite might be estimated as high. It is close to that of pebbles from the Pakri Peninsula (Nemliher \& Puura 1996a).

The lattice parameters and the carbonate content of the studied samples are presented in Table 1. Comparison of the data in Table 1 with those published on fossil lingulates (Ushatinskaya et al. 1988; Nemliher \& Puura 1996a, 1996b) from Upper Cambrian Obolus-conglomerates shows the following relationships:

(1) lattice parameter values of shells and pebbles in Mickwitzia-conglomerate are quite similar, while in Obolus-conglomerate the lattice parameter $a$ of shell apatite is usually greater than that of pebble apatite;

(2) the mineralogical composition and apatite lattice parameters of shells of Mickwitzia sp. are similar to those of pebbles of Late Cambrian age from the Pakri Peninsula;

(3) a slight tendency of the lattice parameter $a$ to decrease towards the east might be assumed, which can be interpreted as a result of diagenetic maturation of phosphatized organic matter rather than as being caused by its primary properties. 
Table 1. Mineralogical parameters of shell apatite of Mickwitzia sp. and pebbles from the Kakumäe Beds

\begin{tabular}{lll|l|c|c}
\hline \multicolumn{1}{c|}{ Sample } & \multicolumn{1}{c|}{ Locality } & \multicolumn{1}{c|}{ Object } & \multicolumn{1}{c}{$a, \AA$} & \multicolumn{1}{c}{$c, \AA$} & $\mathrm{CO}_{3}, \% *$ \\
\hline mk01 & Kakumäe & Mickwitzia & $9.363(4)$ & $6.881(4)$ & 0.4 \\
mur1 & Muraste & pebble & $9.364(1)$ & $6.886(8)$ & 1.2 \\
lk11 & Kose-Lükati & pebble & $9.368(5)$ & $6.883(8)$ & 0.2 \\
lk12 & Kose-Lükati & Mickwitzia & $9.365(5)$ & $6.881(8)$ & 0.3 \\
kkar1 & Kunda quarry & pebble & $9.351(3)$ & $6.889(5)$ & 3.2 \\
kkar2 & Kunda quarry & Mickwitzia & $9.353(9)$ & $6.886(3)$ & 2.3 \\
kjo2 & Kunda River & Mickwitzia & $9.344(5)$ & $6.885(3)$ & 3.4 \\
kjo1 & Kunda River & Mickwitzia & $9.357(8)$ & $6.887(5)$ & 2.1 \\
& & & & & \\
\hline
\end{tabular}

* $\mathrm{CO}_{3}$ content in apatite by Schuffert et al. (1990).

Considering the structure of the shells, all examined specimens of Mickwitzia appeared to be pseudomorphs of apatite-cemented quartzose silt by shells (Pl. I, figs. 2,3). This architecture became evident on specimens with differently preserved shell exterior. The well-ornamented (Pl. I, fig. 1B) shells appeared to be built up in the same way as poorly preserved ones (cf. Pl. I, fig. 1A,B and figs. 2,3). Here, the disappearance of the primary structure, assumed to be characteristic of mickwitziids (McMenamin 1992), and the formation of the presently observed structure are interpreted as the result of the combination of both primary organic matter content of shells and $\mathrm{pH} / \mathrm{Eh}$ conditions during burial. Most probably, early diagenetic conditions were similar to the lithification stage of the basal conglomerate pebbles of the Upper Cambrian Kallavere Formation in the Pakri Peninsula (Nemliher \& Puura 1996a). In comparison with Upper Cambrian obolids, the original shell of Mickwitzia contained more organic matter.

The apatite of the studied shells occurred as c. $10 \mu \mathrm{m}$ thick phosphatic films surrounding quartz particles (Pl. I, fig. 4), or as loose mass (Pl. I, fig. 5) filling cavities. In the latter case, apatite crystals were represented by well-crystallized short hexagonal prisms, c. $1.5 \times 1 \mu \mathrm{m}$ in size (Pl. I, fig. 6).

The data published on structure types of both Recent and fossil brachiopods (Holmer 1989; Williams et al. 1994; Williams \& Cusack 1999) show similarity between Cambrian obolids and Recent lingulids. The primary phosphatic component of these groups is represented by baculi embedded into organic matrix. This structure type probably existed during the Phanerozoic (Williams \& Cusack 1999).

In the studied shells of Mickwitzia even relicts of primary structure were not observed on a large area - from West to East Estonia. Thus it may be concluded that a primary shell structure and composition rather than diagenetic alteration have caused the present shell structure. Here it is assumed that primarily the Mickwitzia shells were built up of a large amount of organic matter, and tiny and 

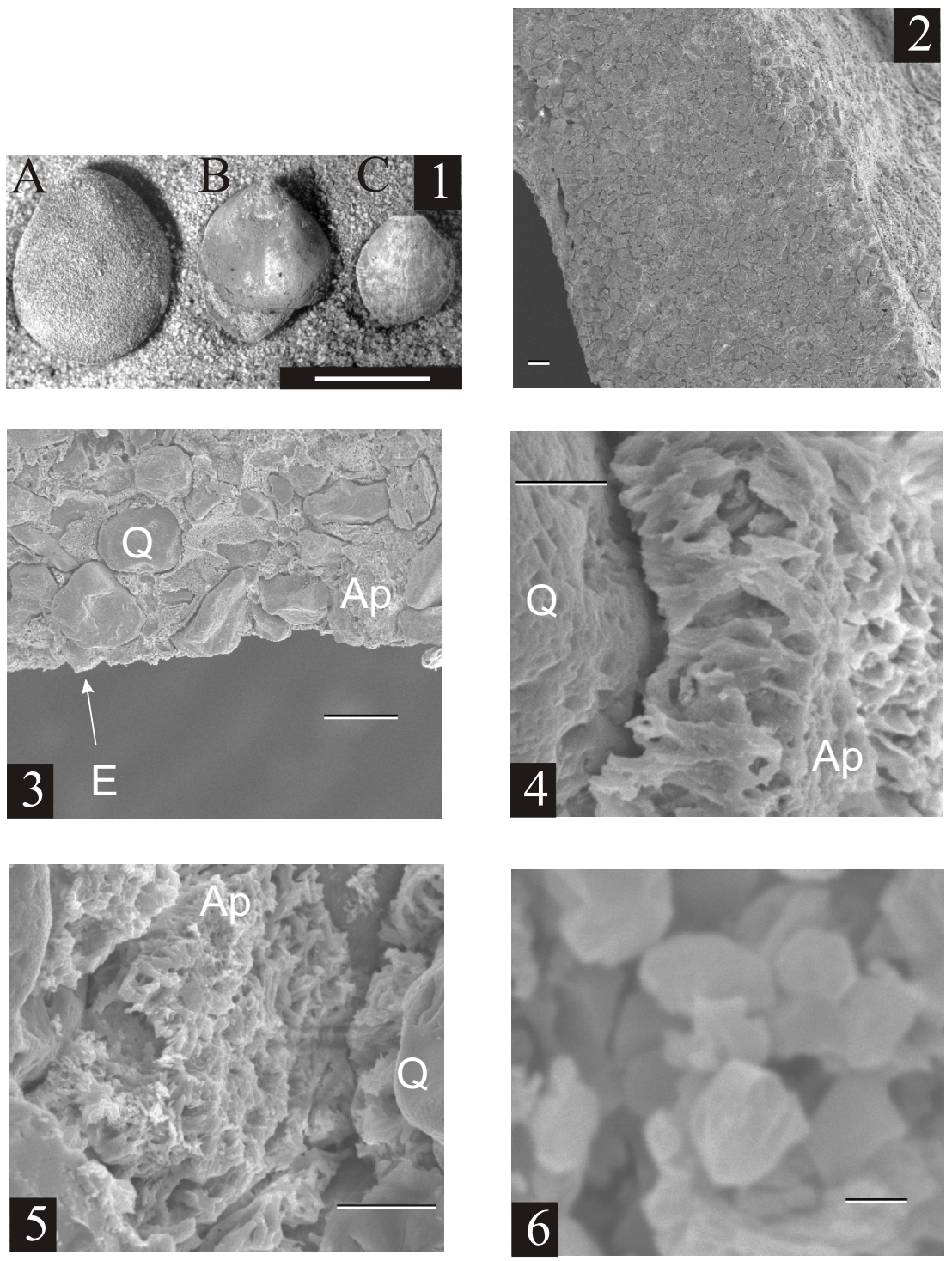

Fig. 1. Variously preserved valves of Mickwitzia sp. A, Kose-Lükati outcrop; B, Kunda River; C, Kunda quarry. Scale bar $2 \mathrm{~cm}$.

Fig. 2. Fractured and etched ( $\mathrm{HCl})$ cross-section of the Mickwitzia valve from Kunda quarry. Valve consists of apatite-cemented silt. Scale bar $100 \mu \mathrm{m}$.

Fig. 3. Polished and etched $(\mathrm{HCl})$ cross-section of the Mickwitzia valve from the Kunda River outcrop. Q, quartz particles; Ap, apatitic cement; E, surface edge of the valve. Scale bar $90 \mu \mathrm{m}$.

Fig. 4. Phosphatic film (Ap) covering the quartz (Q) grain. Fractured and etched $(\mathrm{HCl})$ valve of Mickwitzia, Kose-Lükati outcrop. Scale bar $5 \mu \mathrm{m}$.

Fig. 5. Loose mass of apatite (Ap) filling cavities between quartz (Q) grains. Fractured and etched ( $\mathrm{HCl})$ valve of Mickwitzia, Kose-Lükati outcrop. Scale bar $10 \mu \mathrm{m}$.

Fig. 6. Detail of Fig. 5. Apatite crystals have the shape of well-crystallized plate-like hexagonal prisms. Scale bar $1 \mu \mathrm{m}$. 
isolated apatite crystals represented the phosphatic matter. Also, the organization of apatitic matter supposedly differed from that of obolids (i.e. baculi). The secondary phosphatic matter seems to have been formed via decay and phosphatization of primary shell organic matter (by analogy to the scheme described in Briggs \& Kear 1993), during which particles of the surrounding quartzose sand/silt penetrated into shell space and cemented. The comparatively modest amount of pyrite indicates moderately low Eh conditions during this process.

Some of the studied samples (kjo1) had well-preserved sculpture, while their shell structures appeared to be lost (Pl. I, figs. 1B and 3). Here this is interpreted as being caused by the compact outermost layer (= primary layer?) in the original structure of the shell.

Comparison of the secondary structure types of apatite inside Mickwitzia shells and in pebbles from the Pakri Peninsula revealed similarity in organization of apatitic films as well as loose phosphatic masses. Also, the isotopic and REE composition of apatite of Mickwitzia has been reported as being quite different from that of Upper Cambrian obolids (Lécuyer et al. 1998), probably due to different pathways of diagenetic development of this apatite.

Thus, in the formation of the mineral composition and shell structures recorded in Mickwitzia from Estonia the following stages could be distinguished:

(1) Rapid post mortem changes expressed as phosphatization of primary organic matter in moderately low Eh conditions. During these changes the primary structures disappeared and an additional amount of apatite was generated; the clastic particles that penetrated inside the shell space, where the decay proceeded, were cemented by this phosphatic matter. Therefore, these compact and agglutinated shells were able to resist transportation and became worn out to a different degree.

(2) Diagenetic alteration of shell structures, formation of rims surrounding quartz particles, and orientation of crystals inside these rims, also, maturation of apatite properties (incl. REE patterns and isotopic composition). The highcarbonate apatite modification is supposed to be the starting-point for this phase of changes. However, the formation of loose phosphatic masses consisting of well-crystallized apatite may be considered as a result of later redistribution of previously formed apatite.

\section{ACKNOWLEDGEMENTS}

I am grateful to K. Mens who kindly provided the samples for this study, to T. Kallaste for help with XRD analysis, and E. Pirrus for useful discussions on the subject. Financial support was provided by the Estonian Science Foundation (grant No. 2723) and research project No. 0331427s00. 


\title{
REFERENCES
}

Briggs, D. E. G. \& Kear, A. J. 1993. Fossilization of soft tissue in the laboratory. Science, 259, $1439-1443$.

Gorjansky, V. Yu. 1969. Bezzamkovye brakhiopody kembrijskikh i ordovikskikh otlozhenij SeveroZapada Russkoj platformy. Nedra, Leningrad (in Russian).

Holmer, L. E. 1989. Middle Ordovician phosphatic inarticulate brachiopods form Västergötland and Dalarna, Sweden. Fossils Strata, 26.

Lécuyer, C., Grandjean, P., Barrat, J. A., Emig, C. C., Nõlvak, J., Paris, F. \& Robardet, M. 1998. $\mathrm{d}^{18} \mathrm{O}$ and REE contents of phosphatic brachiopods: a comparison between modern and Lower Paleozoic populations. Geochim. Cosmochim. Acta, 62, 2429-2436.

Linnarsson, J. G. O. 1869. Om några försteningar från Vestergötlands sandstenslager. Öfversigt Konglig Vetenskaps-Akad. Förhandl., 26, 337-357.

McMenamin, M. A. S. 1987. The emergence of animals. Scientific American, 256, 94-102.

McMenamin, M. A. S. 1992. Two new species of the Cambrian genus Mickwitzia. J. Paleont., 66, 173-182.

Mens, K. \& Pirrus, E. 1977. Stratotypes of the Cambrian Formations of Estonia. Valgus, Tallinn.

Nemliher, J. \& Puura, I. 1996a. Upper Cambrian basal conglomerate of the Kallavere Formation on the Pakri Peninsula, NW Estonia. Proc. Estonian Acad. Sci. Geol., 45, 1-8.

Nemliher, J. \& Puura, I. 1996b. Shell mineralogy of the lingulate brachiopods from the Baltic "Obolus phosphorite". In WOGOGOB-94 Symposium, Working Group on Ordovician Geology of Baltoscandia, Bornholm-94 (Stouge, S., ed.), pp. 79-89. Geol. Surv. Denm. Greenland, Report 98.

Öpik, A. 1925. Beitrag zur Stratigraphie und Fauna des estnischen Unter-Kambriums (EophytonSandstein). Publ. Geol. Inst. Univ. Tartu, 3.

Rowell, A. J. 1965. Inarticulata. In Treatise on Invertebrate Palaeontology: Brachiopoda, Vol. 1 (Moore, R. C., ed.), pp. H260-H269. Geol. Soc. Am., Univ. Kansas Pr.

Schmidt, F. 1888. Über eine neuentdeckte untercambrische Fauna in Esthland. Mem. Acad. Imp. Sci. St-Pb, 36.

Schuffert, J. D., Kastner, R., Emanuele, G. \& Jahnke, R. A. 1990. Carbonate-ion substitution in francolite: a new equation. Geochim. Cosmochim. Acta, 54, 2323-2328.

Ushatinskaya, G. T., Zezina, O. N., Popov, L. E. \& Putivtseva, N. V. 1988. On the microstructure and composition of the brachiopods with calcium phosphate shells. Paleontol. Zh., 13, 45-55 (in Russian).

Williams, A. \& Cusack, M. 1999. Evolution of a rhythmic lamination in the organophosphatic shells of brachiopods. J. Struct. Biol., 126, 227-240.

Williams, A., Cusack, M. \& Mackay, S. 1994. Collagenous chitinophosphatic shell of the brachiopod Lingula. Phil. Trans. Roy. Soc. London, B, 346, 223-266.

\section{EESTI ALUSPÕHJA KAKUMÄE KIHTIDEST PÄRINEVA MICKWITZIA (LINGULATA: BRACHIOPODA) POOLMETE STRUKTUUR JA MINERALOOGILINE KOOSTIS}

\author{
Jüri NEMLIHER
}

Röntgenstruktuurianalüüsil tuvastati Kakumäe kihtidest pärinevate Mickwitzia poolmete ja fosfaatsete veeriste koosnemine apatiidist, püriidist ning kvartsist. Poolmete apatiit on hästi kristalliseerunud ja mõõdukalt karbonaatiooni sisaldav 
$(0,2-3,4 \%)$ F-apatiit, mille kristallvõre parameetrid on $a=9,345-9,367 \AA$ ja $c=6,881-6,887 \AA$. Veeriste koostises esineb sama apatiidi modifikatsioon. Kuigi uuritud kollektsiooni poolmete skulptuur on säilinud ebaühtlaselt, on ilmne nende sisestruktuuri täielik hävimine. Poolmed koosnevad apatiidiga tsementeerunud aleuriidiliiva fraktsiooni kvartsiteradest.

\section{СТРУКТУРА И МИНЕРАЛЬНЫЙ СОСТАВ МІСКWITZІА (LINGULATA: BRACHIOPODA) ИЗ КАКУМЯГИСКОЙ ПАЧКИ, ЭСТОНИЯ}

\section{Юри НЕМЛИХЕР}

С помощью рентгеноструктурного анализа установлено, что створки Mickwitzia из какумягиской пачки состоят из апатита, пирита и кварца. Апатит створок характеризуется как хорошо окристаллизованный, умеренно карбонатный $(0,2-3,4 \%)$ фтор-апатит с параметрами ячейки $a=9,345-9,367 \quad \AA \quad$ и $c=6,881-6,887 \AA$. Аналогичная разновидность апатита выявлена в составе фосфатной гальки. Несмотря на вариации степени сохранности скульптуры створок, их внутренняя структура полностью утеряна. Створки состоят из сцементированных апатитом зерен кварца алевритовой размерности. 